\title{
Habitat Assessment of Non-Wadeable Rivers in Michigan
}

\author{
JENNIFER G. O. WILHELM \\ J. DAVID ALLAN* \\ School of Natural Resources and Environment \\ University of Michigan \\ Ann Arbor, MI 48109, USA
}

\section{KELLY J. WESSELL RICHARD W. MERRITT}

Departments of Entomology and Fisheries and Wildlife,

Michigan State University

East Lansing, MI 48824, USA

\section{KENNETH W. CUMMINS}

California Cooperative Fisheries Unit

Department of Fisheries

Humboldt State University

Arcata, CA 95521, USA

ABSTRACT / Habitat evaluation of wadeable streams based on accepted protocols provides a rapid and widely used adjunct to biological assessment. However, little effort has been devoted to habitat evaluation in non-wadeable rivers, where it is likely that protocols will differ and field logistics will be more challenging. We developed and tested a nonwadeable habitat index (NWHI) for rivers of Michigan, where non-wadeable rivers were defined as those of order $\geq 5$, drainage area $\geq 1600 \mathrm{~km}^{2}$, mainstem lengths $\geq 100 \mathrm{~km}$, and mean annual discharge $\geq 15 \mathrm{~m}^{3} / \mathrm{s}$. This identified 22 candi- date rivers that ranged in length from 103 to $825 \mathrm{~km}$ and in drainage area from 1620 to $16,860 \mathrm{~km}^{2}$. We measured 171 individual habitat variables over $2-\mathrm{km}$ reaches at 35 locations on 14 rivers during 2000-2002, where mean wetted width was found to range from 32 to $185 \mathrm{~m}$ and mean thalweg depth from 0.8 to $8.3 \mathrm{~m}$. We used correlation and principal components analysis to reduce the number of variables, and examined the spatial pattern of retained variables to exclude any that appeared to reflect spatial location rather than reach condition, resulting in 12 variables to be considered in the habitat index. The proposed NWHI included seven variables: riparian width, large woody debris, aquatic vegetation, bottom deposition, bank stability, thalweg substrate, and off-channel habitat. These variables were included because of their statistical association with independently derived measures of human disturbance in the riparian zone and the catchment, and because they are considered important in other habitat protocols or to the ecology of large rivers. Five variables were excluded because they were primarily related to river size rather than anthropogenic disturbance. This index correlated strongly with indices of disturbance based on the riparian (adjusted $R^{2}=0.62$ ) and the catchment (adjusted $R^{2}=0.50$ ), and distinguished the 35 river reaches into the categories of poor (2), fair (19), good (13), and excellent (1). Habitat variables retained in the NWHI differ from several used in wadeable streams, and place greater emphasis on known characteristic features of larger rivers.
Large rivers include some of the most pristine lotic systems in the world, as well as some of the most altered. Although some large tropical and boreal rivers have remained largely intact, the large rivers of developed regions have paid a heavy toll for their utility to humankind (Hynes 1989, Arthington and Welcomme 1995). Large rivers are susceptible to cumulative impacts from all upstream land-use activities, in addition to direct impacts from dams, channelization, overharvest, invasive species, and chemical and organic pollu-

KEY WORDS: Riparian; Watershed; Habitat quality; Stream health

Published online August 17, 2005.

*Author to whom correspondence should be addressed; email: dallan@umich.edu tion. Although the latter three factors can affect the biota without damage to physical habitat, many human activities associated with agricultural and urban development and that change existing land-use patterns have been linked to instream habitat degradation (Richards and others 1996, Roth and others 1996, Wang and others 1997).

Habitat assessment has become an important part of the evaluation of ecological integrity (Muhar and Jungwirth 1998) and is incorporated into many stream evaluation protocols (e.g., Wright 1995, Barbour and others 1999). These protocols help to detect human influences and assess the potential of aquatic habitats to support life and maintain ecological integrity (Karr and Dudley 1981, Muhar and Jungwirth 1998). In essence, poor physical habitat conditions lead to expectations 
for degraded biological quality, whereas good habitat conditions should be reflected in high biodiversity, barring other degradation (Plafkin and others 1989).

Existing methods and protocols for assessing physical habitat quality are numerous (for reviews and generalizations of existing protocols see Barbour and others 1999, Fajen and Wehnes 1981, Rankin 1995, Simonson and others 1994, MDNR 1991). However, these efforts have been directed almost exclusively at wadeable streams, and primarily at streams of medium to high gradient (Wang and others 1998). Thus, they prioritize habitats that are uncommon in low gradient streams (Wang and others 1998) and consist of metrics that are either ineffective in non-wadeable environments or infeasible to apply (Edsall and others 1997).

In general, large river ecology has been under-studied because of sampling difficulties related to river size, power, and complexity (Johnson and others 1995). However, the applicability of fundamental stream theories such as the River Continuum Concept (Vannote and others 1980) and the flood-pulse concept (Junk and others 1989) to large rivers has received attention (Minshall and others 1983, Sedell and others 1989, Bayley 1995), and the relative importance of various sources of allochthonous and autochthonous carbon is becoming better understood (Thorp and Delong 1994). Habitats that are unique to large rivers or are of increased importance, such as backwaters (Sheaffer and Nickum 1986, Scott and Nielsen 1989), islands (Thorp 1992), woody snags (Lehtinen and others 1997), and floodplains are increasingly being studied (Petts 1996, Benke 2001). Thus, our understanding of large rivers as ecosystems is advancing steadily.

The development of appropriate indicators to assess the status of, and threats to, large river ecosystems is an important priority (Schiemer 2000). Several indices of biotic integrity have been developed in the past decade for large river fishes (e.g., Simon and Emery 1995, Simon and Sanders 1999, Lyons and others 2001). However, habitat evaluation usually is limited or absent from studies of non-wadeable reaches (e.g., Goldstein and others 2000).

Recent attempts to develop methods for field sampling of large rivers have taken several approaches. Edsall and others (1997) introduced remote sensing techniques to survey the physical habitat of large rivers to be used in conjunction with other National WaterQuality and Assessment (NAWQA) methods, and Gergel and others (2002) proposed relying on landscape indicators for larger systems. Recently, the U.S. Environmental Protection Agency (EPA) (e.g., Flotemersch and others 2000) and the Environmental Monitoring and Assessment Program (e.g., Lazorchak and others 2000) have begun to address issues related to large river sampling logistics and methodologies. Kaufmann (2000) describes a physical habitat assessment protocol for large rivers developed in the western United States. However, these methods have not been sufficiently tested for their applicability in different regions.

Our primary objective was to develop a habitat assessment protocol based on variables that best described physical habitat variability of non-wadeable rivers throughout the State of Michigan, discriminating anthropogenic disturbance from natural variation. Because the quantification of physical habitat potentially must consider a large number of disparate variables, we sought to develop a systematic approach to variable selection in which we first reduced the number of redundant measures, then determined the habitat variables that best described habitat variation among study reaches, and finally selected and weighted metrics for inclusion based on their responsiveness to independently measured gradients of disturbance in the surrounding landscape. However, we also found it necessary to include variables based on their perceived importance to large river ecosystems. This non-wadeable habitat index (NWHI) provides a concise evaluation of the large rivers of Michigan that accords well with independent assessments of disturbance in the landscape surrounding a reach and, used in conjunction with biological protocols (Wessell 2004), shows promise for monitoring and assessment of non-wadeable rivers.

\section{Methods}

\section{Defining Non-Wadeable Rivers}

A non-wadeable or large river can be defined as a reach where the investigator cannot wade along its length (Meador and others 1993) or from bank to bank (Edsall and others 1997). However, the progression from small to large river is continuous, and even the demarcation between wadeable and non-wadeable is an indistinct boundary, because the status of a single location can change between wet and dry months or years. It is desirable to establish guidelines that can be applied prior to visiting a site and used to define the sampling universe of large rivers for a region. Large rivers have been defined as those that exceed a drainage area of $1600 \mathrm{~km}^{2}$ (Ohio EPA 1989); an average depth of $1 \mathrm{~m}$ (Stalnaker and others 1989); a width of 50 $\mathrm{m}$ (Simonson and others 1994); or a river order of six or greater (Vannote and others 1980, Sheehan and Rasmussen 1999). In contrast, Reash (1999) set a much higher threshold by defining a large river as one with a drainage area greater than $20,000 \mathrm{~km}^{2}$. 


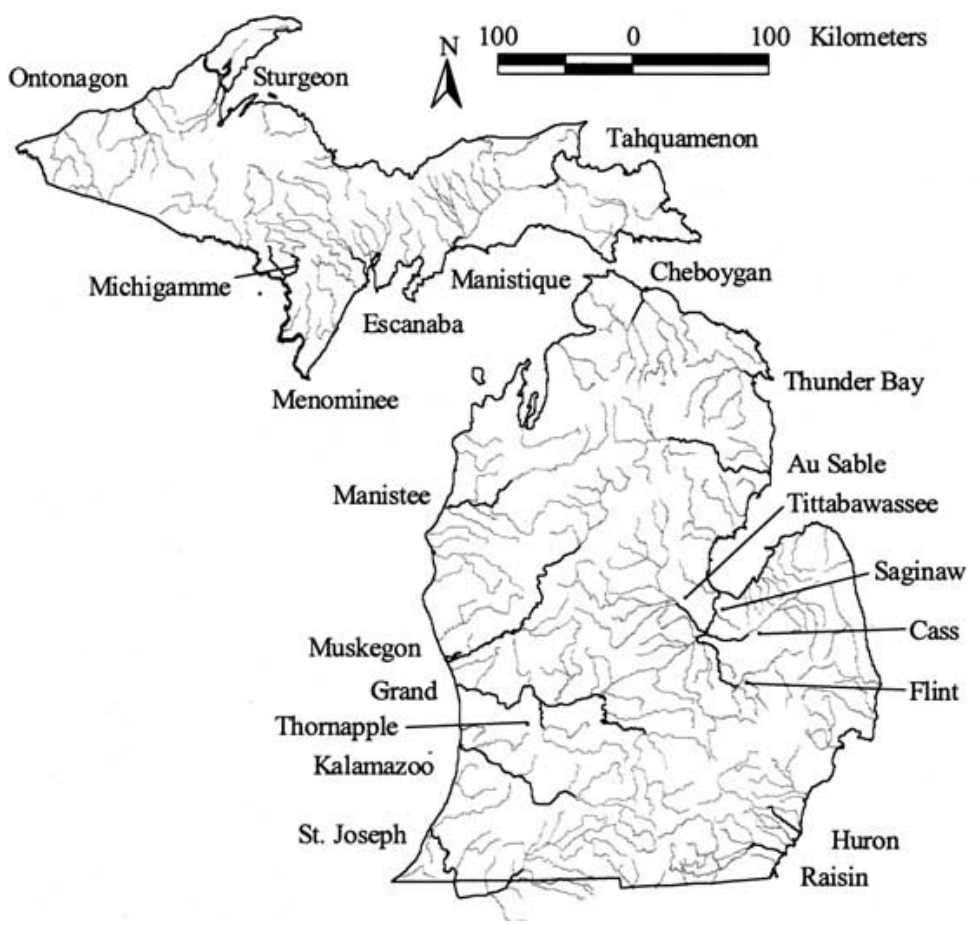

Figure 1. Location of rivers that met criteria for non-wadeable designation (see Table 1). Non-wadeable river segments are bolded.
Most approximations of river size are highly correlated with one another (Leopold and others 1964); however, each measure varies in ease of measurement and accessibility of data. Identification of the nonwadeable rivers of a region requires the selection of one or more criteria, and also of a boundary that, on average, defines a river reach that is non-wadeable during the low flows when most sampling occurs. River systems tend to be small in Michigan because of the short distances from headwaters to river mouths at the Great Lakes (Brown 1944). We define the non-wadeable rivers of Michigan as those that equal or exceed a river order of five, drainage area of $1600 \mathrm{~km}^{2}$, mainstem length of $100 \mathrm{~km}$, and mean annual discharge of $15 \mathrm{~m}^{3} / \mathrm{s}$. We omitted the Detroit and St. Clair Rivers from consideration because they are part of the chain of Great Lakes and experience significant ship traffic, and the Portage River and Canal because it is a ship canal traversing Michigan's Keewenaw Peninsula. Using these initial criteria, we conservatively identified 22 rivers throughout Michigan that had non-wadeable reaches (Figure 1, Table 1). A few additional rivers might have been included had more complete data been available.

\section{Study Systems}

We sampled reaches on 14 Michigan rivers within 11 major watersheds (we sampled three tributaries of the Saginaw as well as its mainstem, accounting for the number discrepancy), ranging in size from the Saginaw River (mainstem $825 \mathrm{~km}$ in length, drainage area $16,856 \mathrm{~km}^{2}$ ) to the Tahquamenon (mainstem length $151 \mathrm{~km}$, drainage area $2124 \mathrm{~km}^{2}$ ) and Huron Rivers (mainstem length $116 \mathrm{~km}$, drainage area $2388 \mathrm{~km}^{2}$ ). Six watersheds were in the Southern Lower Peninsula (SLP), three in the Northern Lower Peninsula (NLP), and two in the Upper Peninsula (UP) (Table 1), thereby encompassing considerable range in climate, vegetation, geology, and anthropogenic disturbances (Albert 1995). According to the classification of Omernik (1976), the UP falls within the Northern Lakes and Forest Ecoregion. The NLP includes the Northern Lakes and Forest, North Central Hardwood Forests, and the northern limit of the Southern Michigan/Northern Indian Clay Plains. The SLP consists mainly of the Southern Michigan/Northern Indian Clay Plains and the Huron/Erie Lake Plain, with a small section of the Eastern Corn Belt Plains. Strong natural gradients in temperature (Wehrly and others 1998), surface vs. groundwater runoff (Wiley and Seelbach 1997), and biological communities (Zorn and others 2002) have been documented for Michigan's rivers.

Current and historic land use also vary markedly across the landscape of Michigan, with a noticeable gradient of increasing anthropogenic influence from north to south as reflected in the 11 major watersheds (Table 2). Natural areas dominate the UP, with nearly 
Table 1. River size can be assessed using several measures including basin area, river length, discharge, and order

\begin{tabular}{|c|c|c|c|c|c|c|}
\hline River & Drainage area $\left(\mathrm{km}^{2}\right)$ & Length $(\mathrm{km})$ & $\operatorname{MAD}\left(\mathrm{m}^{3} / \mathrm{s}\right)$ & Order & Region & Study reaches \\
\hline Saginaw & 16,856 & 825 & 190 & 7 & SLP & 2 \\
\hline Grand & 14,359 & 769 & 107 & 6 & SLP & 7 \\
\hline Menominee & 10,537 & 774 & 89 & - & UP & 2 \\
\hline St. Joseph & 8112 & 492 & 103 & - & SLP & 2 \\
\hline Tittabawassee & 6853 & 343 & 49 & 6 & SLP & 1 \\
\hline Muskegon & 6762 & 335 & 58 & 5 & NLP & 4 \\
\hline Au Sable & 5506 & 267 & 42 & 6 & NLP & 2 \\
\hline Manistee & 5304 & 359 & 58 & 5 & NLP & 4 \\
\hline Kalamazoo & 5084 & 257 & 42 & 5 & SLP & 4 \\
\hline Manistique & 4250 & 314 & 40 & - & UP & 0 \\
\hline Cheboygan & 3919 & 196 & 23 & 6 & NLP & 0 \\
\hline Flint & 3737 & 161 & 21 & 5 & SLP & 0 \\
\hline Ontonagon & 3434 & 248 & 39 & - & UP & 0 \\
\hline Thunder Bay & 3297 & 201 & 26 & 6 & NLP & 0 \\
\hline Raisin & 3090 & 190 & 21 & 5 & SLP & 2 \\
\hline Cass & 2637 & 106 & 15 & 5 & SLP & 1 \\
\hline Shiawassee & 2577 & 151 & 13 & 6 & SLP & 1 \\
\hline Maple & 2461 & 80 & 8 & 5 & SLP & 0 \\
\hline Escanaba & 2391 & 183 & 23 & - & UP & 0 \\
\hline Huron & 2388 & 116 & 18 & 5 & SLP & 1 \\
\hline Tahquamenon & 2124 & 151 & 26 & - & UP & 2 \\
\hline Sturgeon (Houghton Co.) & 2093 & 174 & 23 & - & UP & 0 \\
\hline Pere Marquette & 2051 & 191 & 20 & $<5$ & NLP & 0 \\
\hline Clinton & 2046 & 106 & 16 & $<5$ & SLP & 0 \\
\hline Thornapple & 1961 & 103 & 19 & 5 & SLP & 0 \\
\hline Black & 1686 & 100 & 9 & 5 & SLP & 0 \\
\hline Michigamme & 1621 & 154 & 20 & - & UP & 0 \\
\hline Ford & 1225 & 179 & 11 & - & UP & 0 \\
\hline Paint-Brule & 1191 & 92 & 17 & - & UP & 0 \\
\hline Rifle & 1134 & 80 & 9 & $<5$ & NLP & 0 \\
\hline Sturgeon (Dickinson Co.) & 1041 & 137 & 5 & - & UP & 0 \\
\hline Big Cedar & 1036 & 97 & - & - & UP & 0 \\
\hline Presque Isle & 808 & 122 & 8 & - & UP & 0 \\
\hline
\end{tabular}

Bolded values meet a minimum size requirement: basin area $\geq 1600 \mathrm{~km}^{2}$; length $\geq 100 \mathrm{~km}$; mean annual discharge $(\mathrm{MAD}) \geq 15 \mathrm{~m}{ }^{3} / \mathrm{s} ;$ order $\geq 5$. Italicized rivers satisfy all definitions of 'large'. A dash refers to missing data. River length and drainage area are from Brown (1944); MAD is calculated from USGS gauge data; order is from Folsom and Winters (1970). SLP, Southern Lower Peninsula, NLP, Northern Lower Peninsula, UP, Upper Peninsula.

$90 \%$ of the land forested or covered by wetlands (Albert 1995). Despite extensive logging in the late 19th century, most of the NLP today $(76 \%)$ is forested with a mix of coniferous and deciduous trees, with less than $4 \%$ of the land urbanized and less than $11 \%$ agricultural. The SLP is the most heavily influenced by human activity, with less than $25 \%$ remaining as natural land, more than $8 \%$ urban, and nearly $57 \%$ agriculture.

Differing geology throughout Michigan (Farrand and Bell 1982) influences the contribution of surface runoff or groundwater to rivers (Richards 1990). The porous sand and gravel substrates of the sampled NLP watersheds (61\% outwash and ice contact, Table 3) result in high rates of groundwater input to stream channels. In contrast, the clays and silts of the lake plain region near Michigan's thumb area produce high rates of surface runoff. The Western UP is underlain by resistant bedrock, also resulting in high surface runoff.

\section{Reach Selection}

We selected reaches that fell within river sections that satisfied the non-wadeable criteria (Table 1), provided access via a boat launch, and were not influenced by a nearby dam. We included all geographic regions of the state and attempted to identify reaches encompassing a range of human disturbance within each river sampled to ensure that the finished protocol could detect differences attributed to degradation rather than to individual river characteristics or location within the state. Because of the limited number of nonwadeable rivers and the scarcity of river reaches meet- 
Table 2. Land use within 11 study watersheds grouped by region within Michigan

\begin{tabular}{lccc}
\hline & SLP & NLP & UP \\
& $(\mathrm{n}=6)$ & $(\mathrm{n}=2)$ & 1.3 \\
\hline Urban & 8.2 & 3.7 & $0.7-1.9$ \\
& $3.6-21.0$ & $2.2-4.1$ & 3.2 \\
Agriculture & 56.9 & 10.7 & $0.8-5.6$ \\
Rangeland & $27.0-72.7$ & $3.7-23.0$ & 3.9 \\
& 10.2 & 9.8 & $3.8-4.0$ \\
Forest & $2.6-20.4$ & $5.6-10.0$ & 54.2 \\
& 12.2 & 65.0 & $45.1-63.2$ \\
Wetland & $5.5-31.0$ & $12.0-70.5$ & 35.4 \\
& 12.7 & $10.9-16.2$ & $22.5-48.4$ \\
\hline
\end{tabular}

Values are median and range of percent area. Data are from 1978 MIRIS land use/cover from the Michigan Rivers Inventory database (Seelbach and Wiley 1997). SLP, Southern Lower Peninsula, NLP, Northern Lower Peninsula, UP, Upper Peninsula.

Table 3. Surficial geology within 11 study watersheds grouped by region within Michigan

\begin{tabular}{lccc}
\hline & SLP & UP & UP \\
& $(\mathrm{n}=6)$ & $(\mathrm{n}=3)$ & 43.9 \\
Moraines & 47.4 & 32.8 & $26.8-61.0$ \\
Outwash and ice contact & $33.0-69.8$ & $18.3-44.4$ & 12.5 \\
& 19.2 & 60.8 & $7.5-17.5$ \\
Glacial lake deposits & $11.1-64.1$ & $46.2-72.1$ & 13.4 \\
Organic deposits & 29.3 & 5.6 & $2.1-24.8$ \\
Lakes & $1.9-39.6$ & $4.7-9.0$ & 20.6 \\
Other & 0.0 & 0.0 & $1.6-39.6$ \\
& $0-1.6$ & $0-1.6$ & 0.5 \\
\hline
\end{tabular}

Values are median and range of percent area. Surficial geology data were acquired from the MRI database (Seelbach and Wiley 1997, also Farrand and Bell 1982). SLP, Southern Lower Peninsula, NLP, Northern Lower Peninsula, UP, Upper Peninsula.

ing these criteria, particularly in the southern LP, our sampling includes representative reaches on more than half of the rivers. Thirty-five reaches were visited during summer low flow conditions in 2000, 2001, and 2002, with nine reaches visited multiple times and one that was sampled all 3 years. Thus, our data included 45 sampled reaches but only 35 unique reaches. The repeat visits were primarily used to determine consistency of metrics in year-to-year comparisons (Wilhelm 2002).

A reach length of $2 \mathrm{~km}$ was chosen as a compromise among suggestions found in the literature. Lazorchak and others (2000) recommend a reach length equal to 100 times the wetted width. Because we recorded an average width of $86 \mathrm{~m}$ for the 35 reaches sampled, this criterion would specify a reach length of nearly $9 \mathrm{~km}$, which would require excessive effort. More importantly, it is rarely possible to find reaches of this length that are relatively homogeneous and not disrupted by hydrologic control structures. NAWQA recommends a minimum reach length of $500 \mathrm{~m}$ and a maximum of $1000 \mathrm{~m}$ for non-wadeable sections (Meador and others 1993), which may be insufficient to assess habitat diversity. A reach of 2 $\mathrm{km}$ was logistically feasible to sample in 1 day and, based on preliminary surveys, appeared to capture much of the natural variation in habitat variables within the reach.

\section{Habitat Measurements}

Each 2-km reach included 11 transects at 200-m intervals. Distance between transects was measured using a laser rangefinder. Along both banks at each transect, we established a littoral plot within the river that was $20 \mathrm{~m}$ long $\times 10 \mathrm{~m}$ laterally, and an adjacent riparian plot that also was $20 \times 10 \mathrm{~m}$. A total of 171 habitat variables were measured, estimated, or calculated (Wilhelm 2002), and subsequently grouped within four major categories: a) geomorphology and hydrology, b) substrate, c) instream cover, and d) bank 
and riparian condition (Table 4). Methods were adapted from non-wadeable river pilot studies in Oregon and the Mid-Atlantic Region (Kaufmann 2000), and from other habitat protocols primarily designed for streams and wadeable rivers (e.g., Simonson and others 1994, Fitzpatrick and others 1998, Barbour and others 1999, Kaufmann and others 1999). We calculated a sum, mean, frequency, or coefficient of variation value for each habitat variable for each reach.

At each transect, wetted width and bankfull channel dimensions were measured using a laser rangefinder accurate to $1 \mathrm{~m}$. Within $20 \times 10 \mathrm{~m}$ riparian plots, extent of riparian vegetation was estimated on both banks for canopy and understory layers, including percent cover of trees with diameter at breast height $>0.3 \mathrm{~m}$, small trees, woody shrubs, and grasses. In addition, riparian width was measured using a laser range finder and converted to a proportion of $25 \mathrm{~m}$, the maximum distance that reliable estimates could be made into dense forest. On each bank we measured, noted, or estimated the angle, dominant vegetation, erosion extent, undercut distance if present, and bankfull height.

Human influence included any built surface, riprap, pipes, trash, lawns, and agriculture and was considered within a $20 \mathrm{~m}$ band centered on each transect. Influence was scored based on whether it occurred on the bank, within $10 \mathrm{~m}$, or beyond $10 \mathrm{~m}$. We summed the individual scores for a total visual disturbance metric.

Instream cover for fish was recorded for macrophytes, large woody debris (LWD), overhanging vegetation, boulders, filamentous algae, artificial structures, and undercut banks by estimating percent cover within $20 \times 10 \mathrm{~m}$ littoral plots. For data analysis, we grouped macrophytes and filamentous algae together into a category called aquatic vegetation and everything but artificial structures into a category called natural fish cover.

Velocity, depth, and substrate were measured from an anchored boat at a minimum of 7 points across each transect. Velocity was measured at $0.6 \mathrm{~m}$ depth and to a maximum depth of approximately $1.3 \mathrm{~m}$ from the surface, limited by the length of the flow staff. Because of boat movement, equipment limitations, and water depth, the calculated discharge measures are approximate. Substrate was classified at each anchored point by "feel" with a sounding pole (Kaufmann 2000) as bedrock, boulder, cobble, coarse gravel, fine gravel, sand or fines. The reliability of this method was confirmed by applying it to shallow areas where substrate could be directly observed, and by using a fiber-optic viewer in deeper water. We grouped gravel and larger into coarse substrate and sands and smaller into fine substrate. Secchi depth was measured at mid-channel and expressed as a proportion of $1.5 \mathrm{~m}$ depth, which was the maximum depth of several of the smaller rivers included.

In addition to transect measurements, longitudinal sampling of depth and substrate using a sounding pole was conducted at $40 \mathrm{~m}$ intervals along the thalweg of the entire reach. Off-channel habitat, LWD, and drain pipes entering the channel were tallied. LWD was tallied in several size and length categories, but the final analysis used only number of pieces more than $0.1 \mathrm{~m}$ in diameter and $3 \mathrm{~m}$ in length.

Two composite indices based on visual habitat assessment of wadeable streams, the Michigan Department of Environmental Quality Procedure 51 (MDEQ) (MDNR 1991) and the EPA's rapid bioassessment protocol for low-gradient streams (Barbour and others 1999), also were evaluated for each reach. The MDEQ protocol includes nine metrics: substrate, embeddedness, velocity-to-depth variation, flow stability, bottom deposition, the variety of pools-riffles-runs, bank stability, bank vegetation, and streamside cover. The EPA protocol is similar. Slope and sinuosity were determined from USGS 1:24,000 topographic maps.

\section{Catchment and Riparian Condition}

To identify habitat variables that responded strongly to human disturbance, we evaluated a total of 66 landscape-scale variables in order to assess the extent of human disturbance associated with study reaches independently of the habitat assessment. We obtained 1978 land use/cover data, including roads, from MDNR, and dam and National Pollution Discharge Elimination System (NPDES) permit data from the Surface Water Quality Division of MDEQ. From this information we derived two indices, a Catchment Disturbance Gradient (CDG) and a Riparian Disturbance Gradient (RDG).

The CDG incorporated seven variables, including agricultural land use within the buffer and the upstream catchment; urban land use within the buffer and upstream catchment; and the density of dams, NPDES permits, and roads for the upstream catchment for each reach.

We first examined the proportional land use in urban, agricultural, and forested categories for the area less than $100 \mathrm{~m}$ from the river, 100 to $500 \mathrm{~m}$, and greater than $500 \mathrm{~m}$; for the $2-\mathrm{km}$ reach length, a $10-\mathrm{km}$ segment, and the entire upstream corridor of all tributaries. In addition, we determined land use for the catchment upstream of the study reach, excluding the 500-m buffer (Wilhelm 2002). We retained measures at the smallest buffer scale (100-m buffers for a $10-\mathrm{km}$ 
river segment) and largest scale (entire upstream catchment) because these were weakly correlated (agriculture) or uncorrelated (urban). Within a single scale of measurement, urban, agricultural, and forested land were generally highly correlated, and we retained urban and agricultural measures because they are different anthropogenic disturbances. NPDES permit density and road density both were highly correlated with each other and with catchment urban land. Dam density was uncorrelated with any of the above measures. Although some redundancy remains in the CDG, we elected to retain all variables because they represent different types of anthropogenic disturbance and have the potential to capture important differences in human impact on individual river reaches. Each metric was rated on a five-point scale from 0 to 4 following Ladson and others (1999), by identifying natural breaks using Jenks' optimization (Jenks and Caspall 1971), and metrics were summed to give a total score for the CDG. A low score indicates low disturbance, whereas a high score is indicative of a highly modified reach.

The RDG incorporated only two measures obtained from aerial photographs: riparian width and number of gaps in the riparian for a $2-\mathrm{km}$ river reach. Georectified Digital Orthophoto Quadrangles from 1992 (black and white) and 1998 (color) were imported into ArcView GIS(ESRI), and a centerline was digitized along each reach. Using the Route Hatch ArcView extension, nodes were systematically inserted at 100-m intervals (21 total), and distance to the boundary of forest or wetland vegetation was determined. Gaps including road crossings and any break in the riparian vegetation adjacent to the stream channel were counted and measured, as well as the number of side channels, tributaries, bridges, and islands.

\section{Statistical Analyses}

We reduced the initial 171 habitat measures to a more manageable number of variables using correlation analysis (Spearman's rho) to identify redundant variables within each of the four categories (geomorphology and hydrology, substrate, instream cover, and bank and riparian condition). Highly correlated measures $(r>0.55$ or $r<-0.55, P<0.05$ in all cases, the exact cutoff for each grouping differed) were considered similar or redundant and only one variable was retained. We discarded variables with highly skewed distributions (Goldstein and others 2002) and retained those that were simplest to measure and most consistent in year-to-year comparisons.

Remaining variables were tested for normality using a Shapiro-Wilk test and transformed as needed. We used principal components analysis (PCA) on each habitat grouping to further reduce the number of variables and to identify those that best described the main axes of habitat variation across reaches. We retained axes with eigenvalues $>1$ and selected one variable from each axis for subsequent analysis, typically the variable with the highest absolute loading unless other variables with similar loadings were easier to measure, were known to have higher accuracy or precision, or appeared conceptually preferable versus other selected variables.

To aid in the selection and weighting of variables for inclusion in the NWHI, we used multiple linear regression (MLR) analysis and inspected scatterplots relating the CDG and RDG to habitat variables that were retained subsequent to the PCA. Reaches were split into two groups designated as 'model' (18 reaches) and 'test' (17 reaches). Care was taken that variation in geographic location and reach condition was represented in each group. We then used MLR to determine which habitat variables from the model data responded to these two disturbance measures, and evaluated regression models with the remaining 'test' dataset by comparing the observed vs. estimated disturbance scores. The final NWHI included variables identified by this approach and also variables that were included based on their perceived importance to large river ecosystems. We applied Jenks' optimization (Jenks and Caspall 1971) to cumulative frequency diagrams of each variable to define scoring cutoffs for the final NWHI.

Results

\section{Size Criteria for Non-Wadeable Rivers}

Of the 35 reaches presumed to be non-wadeable, based on the criteria of Table 1, the majority met size criteria proposed in the literature (Stalnaker and others 1989, Simonson and others 1994, Ohio EPA 1989). For all reaches, average depth ranged from 0.6 to 5.6 $\mathrm{m}$, mean thalweg depth from 0.8 to $8.3 \mathrm{~m}$, wetted width from 32 to $183 \mathrm{~m}$, and drainage area from 532 to $15,583 \mathrm{~km}^{2}$.

\section{Identification of Key Habitat Variables}

Elimination of variables on the basis of skewed distributions and redundancy as determined by correlation analysis reduced the habitat data set from 171 to 31 variables (Table 4). Geomorphology and hydrology variables were reduced from 38 to 13 , substrate measures from 55 to 4 , instream cover variables from 29 to 6 , and bank and riparian condition metrics from 49 to 8 . For details of the correlation analysis see Wilhelm (2002). 
Table 4. Summary statistics for 31 habitat variables retained of 171 initial habitat variables

\begin{tabular}{|c|c|c|c|c|c|}
\hline Variable & Transformation & Median & Minimum & Maximum & $\mathrm{n}$ \\
\hline \multicolumn{6}{|l|}{ Geomorphology and hydrology } \\
\hline Discharge $\left(\mathrm{m}^{3} / \mathrm{s}\right)$ & sqrt $(x)$ & 28.8 & 2.0 & 83.3 & 35 \\
\hline Velocity (m/s) & None & 0.29 & 0.02 & 0.56 & 35 \\
\hline Location maximum velocity & None & 0.16 & 0.06 & 0.34 & 35 \\
\hline Drainage area $\left(\mathrm{km}^{2}\right)$ & $\ln (\mathrm{x})$ & 5048 & 532 & 15,583 & 35 \\
\hline Thalweg depth $(\mathrm{m})$ & $\ln (x)$ & 2.0 & 0.8 & 8.3 & 35 \\
\hline Standard deviation thalweg depth $(\mathrm{m})$ & $\ln (x)$ & 0.53 & 0.18 & 3.92 & 35 \\
\hline Maximum depth (m) & $\ln (\mathrm{x})$ & 2.4 & 1.0 & 8.1 & 35 \\
\hline Location maximum depth & None & 0.21 & 0.07 & 0.35 & 35 \\
\hline Wetted width $(\mathrm{m})$ & $\ln (x)$ & 76 & 32 & 183 & 35 \\
\hline Wetted width to depth ratio & $\ln (x)$ & 56 & 16 & 147 & 35 \\
\hline Bankfull height $(\mathrm{m})$ & $\ln (x)$ & 0.6 & 0.1 & 2.3 & 35 \\
\hline Sinuosity & $1 /(\mathrm{x})$ & 1.22 & 1.01 & 2.97 & 35 \\
\hline Slope $(\mathrm{m} / \mathrm{m})$ & $\ln (\mathrm{x})$ & $3.6 \mathrm{E}-04$ & $7.2 \mathrm{E}-05$ & $1.3 \mathrm{E}-03$ & 35 \\
\hline \multicolumn{6}{|l|}{ Substrate } \\
\hline Coarse thalweg substrate $(\%)$ & None & 35 & 0 & 100 & $33^{\mathrm{a}}$ \\
\hline Fine substrate in shallows $(\%)$ & None & 83 & 13 & 100 & $34^{\mathrm{a}}$ \\
\hline Coarse substrate in shallows $(\%)$ & $\operatorname{asin}(\operatorname{sqrt}(x))$ & 13 & 0 & 78 & $34^{\mathrm{a}}$ \\
\hline Bottom deposition (MDEQ-5) & None & 11 & 2 & 15 & 35 \\
\hline \multicolumn{6}{|l|}{ Instream cover } \\
\hline LWD quantity (no. of pieces) & None & 72 & 3 & 306 & 35 \\
\hline LWD volume $\left(\mathrm{m}^{3} /\right.$ piece $)$ & None & 0.25 & 0.03 & 0.65 & 35 \\
\hline Quantity of off-channel habitat (no.) & $\ln (x+1)$ & 2 & 0 & 10 & 35 \\
\hline Secchi depth $(\%$ of $1.5 \mathrm{~m})$ & $\ln (x+1)$ & 25 & 3 & 65 & 35 \\
\hline Aquatic vegetation (\% cover) & $\ln (x+1)$ & 10 & 0 & 59 & 35 \\
\hline Natural fish cover (\% cover) & None & 41 & 0 & 122 & 35 \\
\hline \multicolumn{6}{|l|}{ Bank and riparian condition } \\
\hline Riparian width $(\mathrm{m})$ & $\operatorname{asin}(\operatorname{sqrt}(x))$ & 19 & 4 & $>25$ & 35 \\
\hline Woody shrubs (\% cover) & None & 21 & 7 & 58 & 35 \\
\hline Bank angle (degrees) & None & 51 & 16 & 78 & 35 \\
\hline Undercut distance $(\mathrm{m})$ & None & 0.4 & 0.0 & 0.9 & $33^{\mathrm{b}}$ \\
\hline Riparian cover (\% cover) & None & 125 & 48 & 185 & 35 \\
\hline Human disturbance (score) & $\ln (x+1)$ & 3.9 & 0.0 & 11.7 & 35 \\
\hline Bank stability (MDEQ-7) & None & 8.4 & 6.8 & 10.0 & 35 \\
\hline Bank vegetative stability (MDEQ-8) & $\operatorname{asin}(\operatorname{sqrt}(x))$ & 8.1 & 2.8 & 10.0 & 35 \\
\hline
\end{tabular}

${ }^{\mathrm{a}}$ No data taken from dredged river channels.

${ }^{\mathrm{b}}$ Data missing for two reaches.

Median, minimum, and maximum values are for untransformed values across all reaches. The transformation used in subsequent analyses is shown.

MDEQ, Michigan Department of Environmental Quality procedure 51; LWD, large woody debris.

PCA applied to each habitat subgrouping identified 12 core habitat variables that best explained habitat variability among the 35 study reaches (Table 5 ). The first four axes from the PCA of the geomorphology and hydrology group explained $75 \%$ of the variation among reaches. Thalweg depth, wetted width-to-depth ratio, discharge, and slope were selected for further analysis based on high variable loadings on axes one, two, three, and four respectively, as well as their ease of measurement and interpretation. Axis five did not have any highly loaded variables and explained less than $9 \%$ of the remaining variation; therefore, no variable was retained despite an eigenvalue of 1.12.

For substrate, the first two axes of the PCA explained $79 \%$ of the variation among reaches (Table 5).
Visually assessed bottom deposition (MDEQ metric 5) was selected over percent fine substrate on the first axis, and coarse thalweg substrate was retained over coarse shallow substrate on axis two, despite slightly lower loadings, because of their ease of measurement.

The first three axes of the instream cover PCA explained more than $73 \%$ of the variation among reaches (Table 5). Aquatic vegetation, quantity of LWD, and off-channel habitat were selected due to their high loadings on the first three axes.

The first three axes of the bank and riparian condition PCA explained more than $77 \%$ of the variation among reaches (Table 5). Three measures were heavily loaded on axis one, including the composite visual disturbance metric, riparian width, and bank vegetative 
Table 5. Twelve variables were retained from principal components (PC) analysis of the model data for each habitat variable grouping

\begin{tabular}{|c|c|c|c|c|c|}
\hline Variable grouping & PC1 & PC2 & PC3 & PC4 & $\begin{array}{l}\text { Cumulative variance } \\
\text { explained }(\%)\end{array}$ \\
\hline \multicolumn{6}{|l|}{ Geomorphology and hydrology } \\
\hline Variable selected & Thalweg depth & $\begin{array}{l}\text { Wetted width- } \\
\text { to-depth ratio }\end{array}$ & Discharge & Slope & \\
\hline Variance explained by axis & 28.6 & 21.8 & 15.3 & 9.3 & 74.9 \\
\hline \multicolumn{6}{|l|}{ Substrate } \\
\hline Variable selected & Bottom deposition & $\begin{array}{l}\text { Coarse thalweg } \\
\text { substrate }\end{array}$ & & & \\
\hline Variance explained by axis & 46.8 & 32.6 & & & 79.4 \\
\hline \multicolumn{6}{|l|}{ Instream cover } \\
\hline Variable selected & Aquatic vegetation & Quantity LWD & $\begin{array}{l}\text { Off-channel } \\
\text { habitat }\end{array}$ & & \\
\hline Variance explained by axis & 29.5 & 25.7 & 17.4 & & 72.6 \\
\hline \multicolumn{6}{|l|}{ Bank and riparian condition } \\
\hline Variable selected & Riparian width & Bank stability & Bank angle & & \\
\hline Variance explained by axis & 34.2 & 26.8 & 16.3 & & 77.4 \\
\hline
\end{tabular}

One high-loading variable was selected to represent each component based on an eigenvalue $>1$.

LWD, large woody debris.

stability (MDEQ metric 8). Riparian width was selected since it is easily obtained on-site compared to the calculations required to obtain the visual human impact metric, and is more quantitative than the MDEQ metric. In addition, riparian width yields a measurement that is easily understood, whereas the visual disturbance value is only useful relative to other reaches. Visually assessed bank stability (MDEQ metric 7) was selected for its high loading on axis two over other measures of riparian composition that seemed conceptually redundant with riparian width. Bank angle had high loadings on axis three and was therefore selected.

Habitat variables could have high PCA loadings because they distinguish reaches based on location (e.g., within a region or a particular river) rather than on habitat quality and human disturbance. Because inspection of scatterplots of PCA 1 vs. PCA 2 for each of the four habitat groups revealed minimal spatial pattern for the identified variables (Figure 2), the habitat variation within our data set appears to reflect site quality rather than spatial location. Although instream cover exhibited some tendency towards spatial separation between NLP and SLP reaches, reaches within rivers did not cluster, and the latitudinal gradient was judged to be influenced more by human disturbance than by a natural gradient. Thus, all 12 variables were retained for evaluation against the disturbance gradients.

\section{Anthropogenic Disturbance Gradients}

The extent of anthropogenic disturbance associated with reaches differed markedly based on the two indi- ces, with the CDG ranging from 0 to 14 out of a possible 28 points and the RDG ranging from 0 to 8 out of a possible 8 points. The CDG and RDG were significantly correlated $(r=0.66, P<0.001)$, despite being derived at different spatial scales and from different data sources.

The CDG $\left(\mathrm{F}_{2,32}=46.8, P<0.0001\right)$ and the RDG $\left(\mathrm{F}_{2,32}=5.77, P=0.007\right)$ both differed significantly by location (Figure 3). Using Tukey's method for paired comparisons, significant differences were found in the CDG between the SLP and the NLP $(P<0.0001)$ and the SLP and UP $(P<0.0001)$, and in the RDG between the SLP and the UP $(P=0.0007)$. UP reaches were scored as markedly less disturbed by both indices, and differences between the NLP and SLP were more pronounced using the CDG vs. the RDG. In addition, 3 of the 11 rivers had study reaches that encompassed the full range of RDG scores, which was not the case with the CDG. For these reasons, it appears that the RDG may be a more appropriate indicator of anthropogenic disturbance to rivers than the CDG, because it is less strongly location dependent.

\section{Selection of NWHI Variables}

To evaluate the responsiveness of habitat variables to anthropogenic disturbance, we examined the strength of statistical associations of the 12 remaining habitat variables with the independently derived CDG and RDG for the 18 model reaches using MLR (Table 6). For the CDG, stepwise backward regression resulted in a significant model $(P<0.001)$ with an adjusted $\mathrm{R}^{2}$ of 0.78 . Retained variables included 


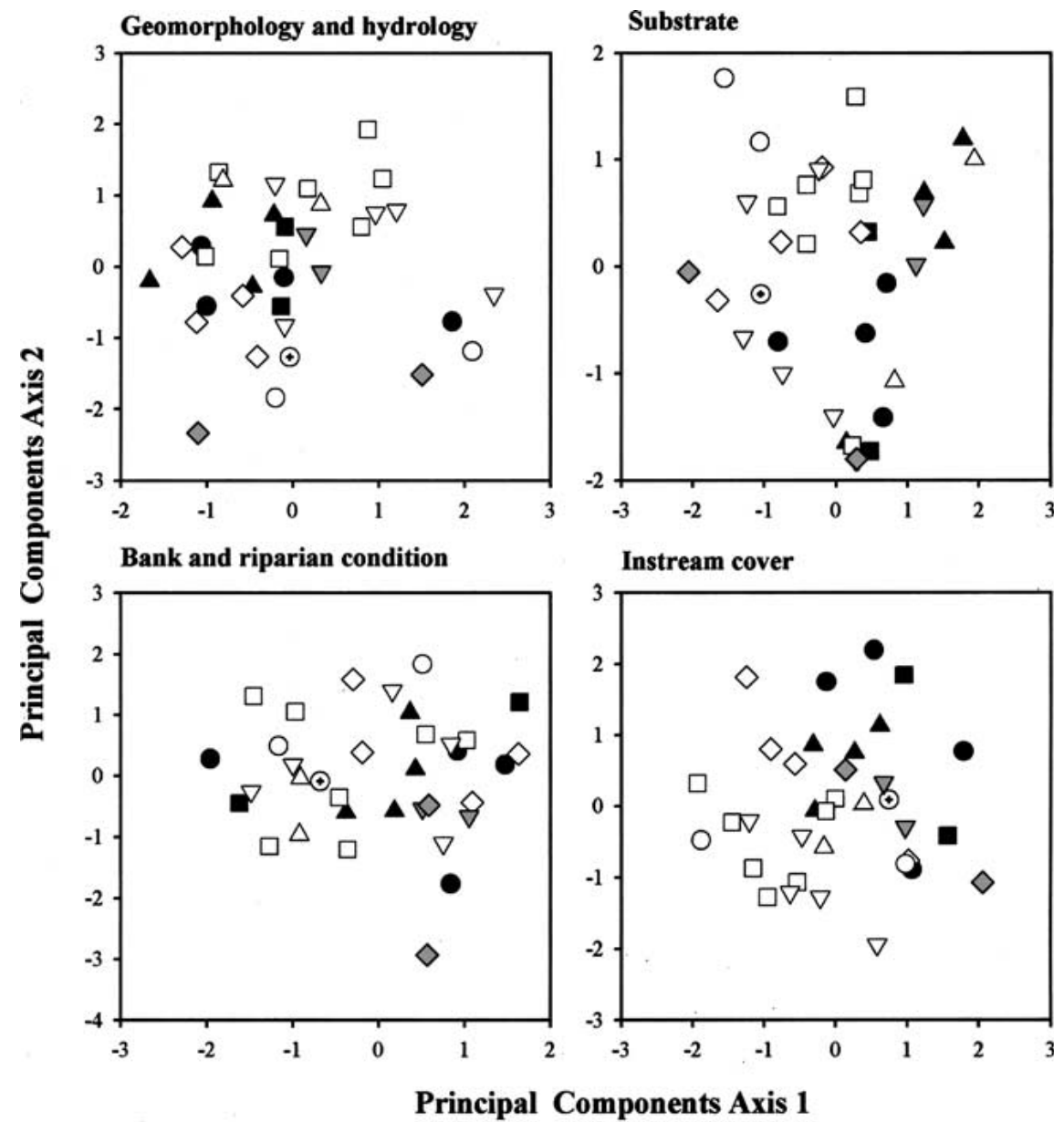

Figure 2. Spatial relationships among river reaches for each of the four groups of habitat variables. SLP, open symbols; NLP, closed symbols; UP, gray-tone symbols. Au Sable (ם), Manistee (๑),

Muskegon ( $\mathbf{\Delta})$, Grand $(\square)$, Huron $(\odot)$, Kalamazoo $(\diamond)$, Raisin $(\bigcirc)$, Saginaw $(\nabla)$, St. Joseph $(\triangle)$, Menominee $(\nabla)$, Tahquamenon $(\diamond)$. Some spatial dependency is evident for instream cover variables. Reaches within rivers show little tendency to cluster, suggesting that habitat metrics reflect reach quality rather than river or region.
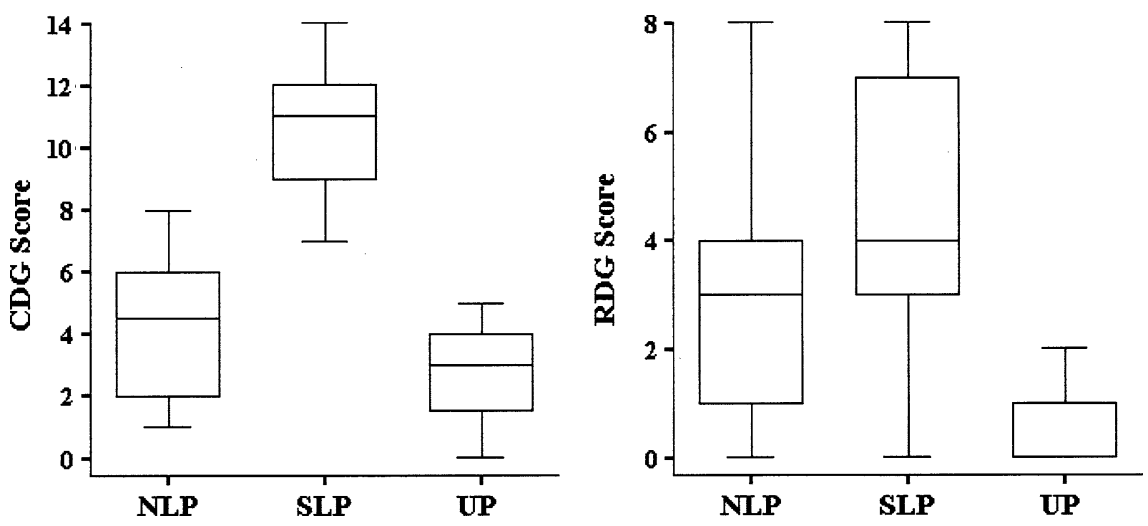

Figure 3. Catchment (left) and riparian (right) disturbance gradients depicted for three regions of Michigan to investigate north-south anthropogenic gradient. SLP, southern Lower Peninsula; NLP, northern Lower Peninsula; UP, Upper Peninsula. Median, quartiles, maximum and minimum values are displayed.

quantity of LWD, aquatic vegetation, and riparian width. However, the model's predictive power was found to be modest when used to estimate the CDG from habitat data at test sites, resulting in an adjusted $\mathrm{R}^{2}$ of 0.34 between predicted and observed CDG. This model consistently overpredicted the disturbance gradient, especially at the least disturbed reaches. The estimated disturbance scores ranged from 5.6 to 12.4 compared to the observed disturbance scores from 0 to 13.

For the RDG, backward stepwise regression retained only one variable, riparian width, with an adjusted $\mathrm{R}^{2}$ of 0.75 (Table 6 ). Using this model with the test data resulted in a relatively good fit of observed versus pre- 
Table 6. Backward stepwise multiple linear regression using the model data identified habitat variables that were the best predictors of the disturbance gradients

\begin{tabular}{lccllrrr}
\hline Dependent variable & Adj. $\mathrm{R}^{2}$ & $P$-value & $\mathrm{X}_{1}$ & $\mathrm{X}_{2}$ & $\begin{array}{l}\mathrm{O} / \mathrm{E} \\
\text { Adj. } \mathrm{R}^{2}\end{array}$ & $\begin{array}{l}\mathrm{O} / \mathrm{E} \\
P \text {-value }\end{array}$ \\
\hline CDG & & & & & Riparian Width & 0.34 & $<0.008$ \\
RDG & 0.78 & $<0.001$ & Quantity LWD & Aquatic Vegetation & Rian & 0.73 & $<0.001$ \\
\hline
\end{tabular}

Expected values (E) for both disturbance gradients were estimated using habitat information from test reaches, and compared to observed values (O) of the two disturbance gradients. Three habitat variables selected by stepwise models appear to be the strongest indicators of human disturbance.

CDG, catchment disturbance gradient; RDG, riparian disturbance gradient; LWD, large woody debris.

dicted RDG values, explaining $73 \%$ of the variation. This model also tended to consistently overpredict disturbance for the most natural reaches, although not as markedly as the CDG model. The estimated disturbance scores ranged from 1.4 to 6.8 , compared to the observed score range from 0 to 8 .

A strong relationship between aerial photo measures of riparian width (included in the RDG) and the river habitat riparian metric is expected, and could 'mask' other river habitat variables that might otherwise be implicated. Repeating the regression with riparian width excluded resulted in a model that retained offchannel habitat, bottom deposition, quantity of LWD, and thalweg substrate (adjusted $\mathrm{R}^{2}=0.35$ ). Although this analysis suggests additional variables for inclusion in the habitat index, the predictive ability of this model when applied to the test data was poor (adjusted $\left.\mathrm{R}^{2}=0.02\right)$.

\section{Constructing the NWHI}

Based on the two disturbance gradients, riparian width, LWD, and aquatic vegetation are particularly important components of habitat quality in these nonwadeable rivers. Bivariate scatter plots further illustrate their relationships with the disturbance gradients $(P<$ 0.05 ; Figure 4$)$, and suggest that bottom deposition also should be included. These four variables are useful in developing an index that can distinguish reaches with poor vs. good habitat, using the disturbance gradients as the measure of 'poor' and 'good.'

Although the remaining eight variables were not selected in the CDG and RDG models, three can be justified for inclusion in the final index based on perceived importance. Bank stability and substrate size are important measures of habitat frequently included in assessment protocols. Substrate composition provides microhabitat for fishes (Mebane 2001) and influences macroinvertebrate (Beisel and others 2000) and freshwater mussel (Lewis and Riebel 1984) distribution and abundance. Large, stable substrate is generally considered more favorable for epifaunal colonization and fish cover (Barbour and others 1999). Stable banks provide cover and reduce nutrient and sediment inputs to the stream, which can be detrimental to the biota (Stevenson and Mills 1999). In large rivers, offchannel habitat may play a role of increased importance as biological hotspots (Reash 1999), places of refugia during disturbance events, regions of nutrient enrichment, and spawning or nursery areas (Sheaffer and Nickum 1986, Scott and Nielsen 1989). Therefore, despite the lack of strong relationships with the disturbance gradients, off-channel habitat, bank stability, and thalweg substrate were included in the final habitat index. This decision receives further support from the finding that off-channel habitat and thalweg substrate (as well as bottom deposition) were included in the RDG regression that excluded the field riparian metric.

The five remaining variables identified as important in describing habitat variability (discharge, thalweg depth, slope, width-to-depth ratio, and bank angle) are not easily associated with a scale of anthropogenic disturbance, and several are strongly associated with river size. Discharge, thalweg depth, width-to-depth ratio, and slope may be helpful in determining biological or habitat expectations for a given reach, but not in determining reach quality. We recommend measuring thalweg depth, as opposed to discharge, as a surrogate for river size; slope to define expectations for habitat features; and width-to-depth ratio to characterize the general channel shape. However, we do not assign a corresponding quality scale nor include these in the NWHI.

Bank angle was the final variable that was not correlated with the disturbance indices and appeared to provide little information about habitat quality. Because of difficulties in measuring bank angle, and its conceptual redundancy with the selected MDEQ bank stability metric, no bank angle measurement was included in the final habitat index.

In summary, riparian width, $L W D$, aquatic vegetation, thalweg substrate, bottom deposition, off-channel 

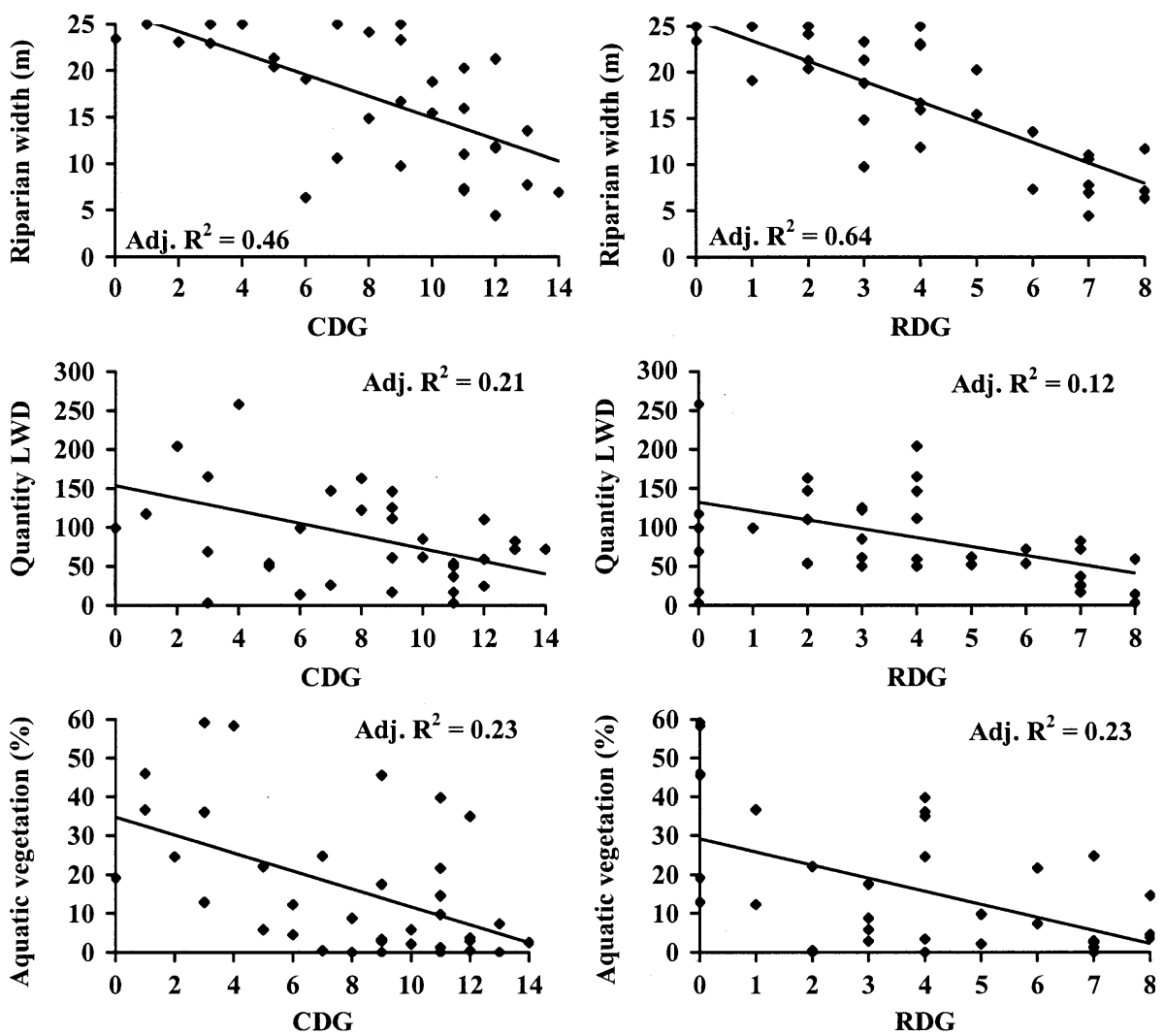

Figure 4. Several variables considered for inclusion in the non-wadeable habitat index were significantly correlated with either the Catchment Disturbance Gradient (CDG) or the Riparian Disturbance Gradient (RDG) $(P<0.05)$. Appropriate transformations to meet the normality assumption were performed (see Table 4), however, untransformed data are displayed here. Trend lines represent linear regressions.

habitat, and bank stability are the seven habitat variables evaluated in the habitat index to determine habitat quality at a given reach (Table 7). Due to their selection in regression models, woody debris, aquatic vegetation, and riparian width were given the highest weight. Riparian width was scored on a 25-point scale due to its relation with both disturbance gradients, whereas LWD and aquatic vegetation were scored on a 20-point scale. This weighting also agreed with field observations: reaches with abundant wood, established macrophytes, and an intact, natural riparian buffer consistently appeared to have extensive high-quality river habitat compared to other reaches. Bottom deposition, thalweg substrate, and bank stability were given an intermediate weight and were scored on a 10point scale. Off-channel habitat was given the lowest weight and was scored on a 5-point scale. This variable was the weakest measure in the instream cover grouping based on the PCA.

\section{Habitat Quality of Michigan Rivers}

The 35 non-wadeable river reaches sampled during 2000-2002 ranged in NWHI scores from 25 points for an urban reach of the Grand River to 85 points for a forested reach on the Manistee River, out of a possible 100 points (Figure 5). By summing across the seven metrics, we established criteria for reaches that are excellent (84-100), good (56-84), fair (28-56), and poor (0-28). Of the 35 evaluated reaches, 1 was ranked excellent, 13 were good, 19 were fair, and 3 ranked as poor. The mean score was just under 52 and the median score was 50 , both of which fell in the fair category for overall habitat quality. 


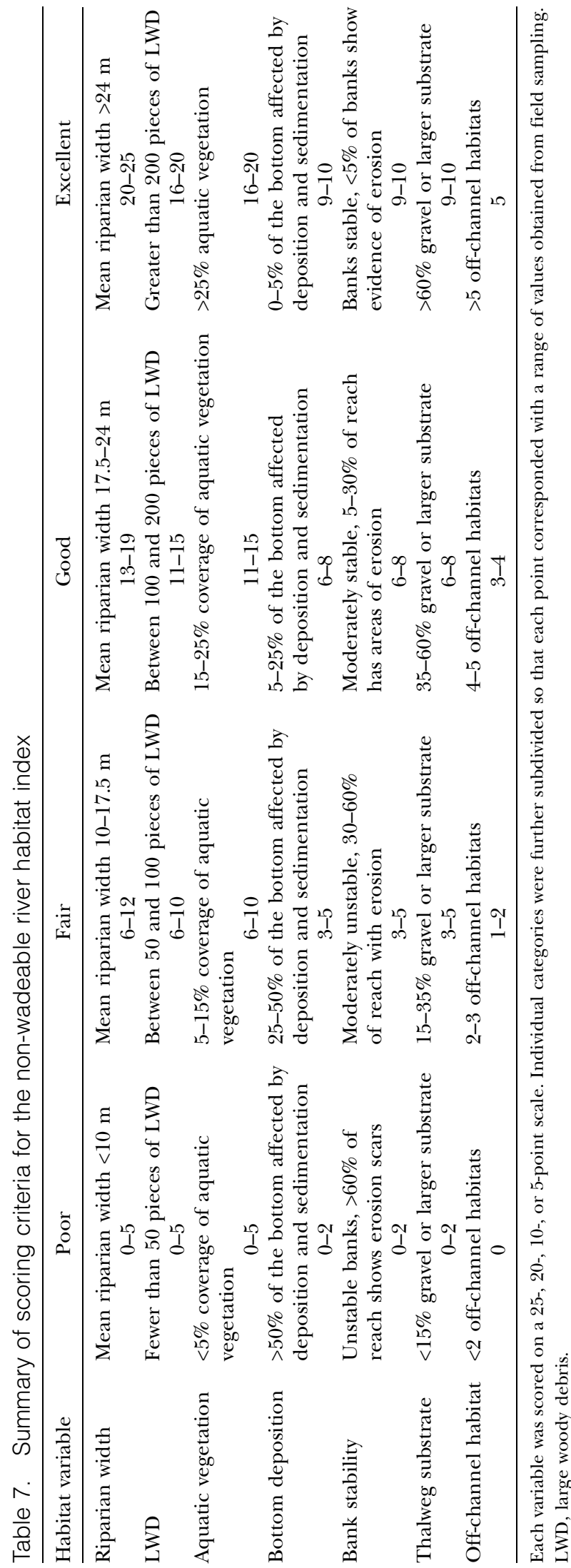

NWHI scores were highly correlated with both the EPA and MDEQ visual assessment scores $(P<0.001)$, despite the inclusion of several different measures of habitat quality in the latter indices. NWHI scores were also significantly correlated with disturbance gradient scores $(P<0.001$; Figure 6$)$. The spatial distribution of NWHI scores suggests that they were not strongly location dependent (Figure 5). The Manistee and Grand Rivers both had reaches covering at least three of the four categories of poor to excellent.

NWHI scores were calculated for the three regional groupings and were significantly different $\left(\mathrm{F}_{2,32}\right.$, $P=0.003)$. In general, reaches in the SLP had the lowest mean score (44), UP reaches had intermediate scores (61), and the NLP reaches had the highest scores (63).

\section{Discussion}

Habitat lies at the interface between the forces structuring rivers and the organisms that inhabit them (Harper and Everard 1998), thereby providing a link between the physical environment and its residents (Maddock 1999). Habitat condition has been shown to influence species composition, diversity, abundance, and productivity within a river segment (Gorman and Karr 1978, Harper and Everard 1998). Habitat degradation has resulted in extinctions, local extirpations, reduced populations, and other modifications of aquatic fauna throughout the United States (Karr 1991) and is recognized as one of the most important causes of the decline of biodiversity in fluvial ecosystems (Allan and Flecker 1993). However, habitat evaluation of large rivers is hampered by the absence of a standard protocol that addresses their logistical challenges and specific habitat features.

Because large rivers are the ultimate sinks of pollution and cumulative landscape effects, it may be appropriate to use large rivers to monitor the ecological health of the whole drainage basin (Hynes 1989). Indeed, it is becoming accepted that, if a stream is assessed as unhealthy, then the catchment also is unhealthy (Norris and Thoms 1999).

The weighting of metrics included in the NWHI reflects the strength of statistical association of each with independent measures of anthropogenic disturbance, as well as knowledge of the ecological role of the variables represented. A high weighting for natural riparian areas is expected because of their dynamic interaction with lowland, floodplain rivers (Vannote and others 1980) and their essential roles in nutrient and sediment retention, as sources of wood and leaf 

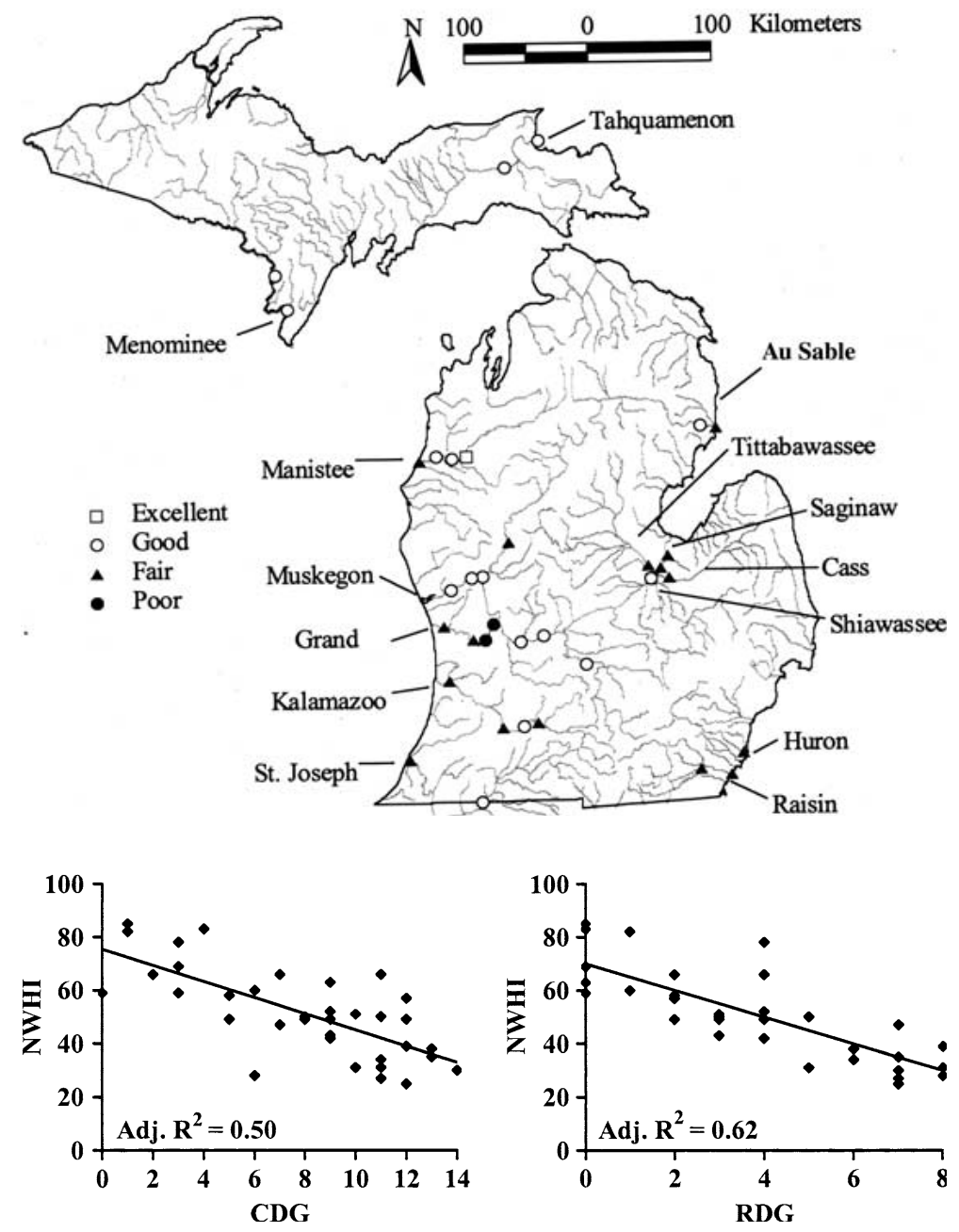

Figure 5. Spatial distribution of assessed habitat quality for 35 non-wadeable reaches on rivers of Michigan. Reaches ranked "good" occurred throughout the state, and reaches on a single river received as many as three different rankings, suggesting that the nonwadeable habitat index evaluates reach quality regardless of location. debris, and in bank stabilization and providing overhanging cover (Gregory and others 1991).

It is not surprising that riparian width recorded from the river channel was strongly implicated in regressions with both the CDG and RDG, because the disturbance metrics also included information on the riparian zone. Although the RDG evaluated riparian vegetation at a larger scale $(10 \mathrm{~km}$ in length, to the lateral extent of forest or wetland) than the field riparian metric, their high correlation suggests that these are in fact two measures of local-scale riparian condition, perhaps most useful in establishing that riparian condition varies more on the local scale than does catchment condition. The fact that unique reaches along the same river differed in total habitat quality is a strong indicator that the local riparian area is an important influencing force and that natural buffers do protect the river from larger-scale human impacts. These findings support the view that variation in local, reach-scale riparian conditions influences habitat quality of non-wadeable rivers, and presumably the biota as well.
The NWHI also gives significant weight to aquatic vegetation and woody debris. Macrophytes and LWD are important components of instream habitat structure, loss of which may significantly reduce fish populations and biodiversity. In the rivers sampled, they were frequently the primary stable substrates and were important in contributing to localized areas of hydraulic diversity.

Inclusion of bottom deposition, bank stability, thalweg substrate, and off-channel habitat is justified based on ecological understanding of their importance, and to some extent by statistical findings, although these variables were less strongly implicated. Thus, their inclusion with lower weighting appears appropriate.

The two wadeable habitat protocols (MDEQ and EPA) were highly correlated with the NWHI. Although this might suggest that existing, wadeable stream indices can be used in larger rivers, we believe that the NWHI is an improvement over these. First, the NWHI includes some metrics and excludes 
others in accordance with basic knowledge of small streams versus larger rivers. Several variables commonly used in wadeable indices are notably absent, including pool variability, channel flow status, and sinuosity, either because they were not applicable to large river systems or showed little variation in rivers throughout Michigan. Although the relative change in width and habitat with flow can be considerable in small rivers, where extreme low flows can be especially damaging (Jowett 1997), larger rivers in Michigan usually have ample flows and the appearance of adequate wetted habitat. Similarly, wadeable protocols tend to estimate habitat representation of deep and shallow pools, runs, and riffles. The primary geomorphic units in large rivers are bends and crossover regions instead of pools, riffles, and runs (Leopold and others 1964, Fitzpatrick and others 1998). Run or glide was the overwhelmingly dominant habitat type in the rivers sampled and therefore always scored in the poor or fair categories. In addition, our NWHI included off-channel habitats, which are recognized as biologically rich locations within large rivers (Stalnaker and others 1989, Reash 1999), and are not normally considered in traditional wadeable habitat protocols. It may be desirable to expand this metric to assess various forms of channel and hydraulic complexity by considering backwater, off-channel, tributary and island habitats, which exhibit extensive variation in large floodplain rivers (Kellerhals and Church 1989).

Second, the wadeable protocols grouped all the reaches together in the fair and good categories. The EPA method scored no reaches as 'poor,' whereas the MDEQ protocol scored no reaches in the 'excellent' or 'poor' range. In contrast, the distribution of scores for the NWHI (Figure 5) included all categories from poor to excellent with the majority of reaches scored as fair, compared to the good rating received by most reaches using the visual methods for wadeable streams.

Finally, the NWHI involved many quantitative metrics rather than visually estimated measures and was developed using statistical procedures and objective criteria as much as possible to avoid personal bias, subjectivity, and constraints of knowledge (Boulton 1999).

We used the CDG and RDG as criteria to identify habitat variables that were sensitive to anthropogenic impacts based on the view that catchment and/or riparian character influences the river (Allan and Johnson 1997). An alternative approach would be to use biological data to select habitat variables that predict, for example, best conditions for fish (Wang and others 1998). Such data were unavailable for this study, although a comparison between the NWHI and macroinvertebrate indices is forthcoming (Wessell 2004). We believe our approach is warranted as a test of the hypothesis that altered land use directly impacts habitat, which in turn influences the biota; and because it allows the subsequent comparisons of habitat and biological metrics to use independently derived metrics.

Ideally, the final index would be calibrated against existing reference reaches to define best attainable habitat conditions. However, because of extensive logging throughout the state in the late 1800 s, in addition to current agricultural practices, urban development, pollution, and hydrological modification due to dams and channelization, few river reaches can truly be considered natural or unmodified. Therefore, there are relatively few large rivers in Michigan from which to derive comparisons, a general concern in referencing large rivers (Norris and Thoms 1999). Without a sufficient number of unimpacted reaches from which to draw baseline comparisons, the cumulative dataset was used to derive variations in attainable conditions ( $\mathrm{Si}$ mon 1991). This resulted in a relative scale of habitat quality ranging from poor to excellent, whereas comparison to presettlement conditions might indicate that few of Southern Michigan's larger rivers can be regarded as healthy. Although the final habitat index has not yet been tested extensively for its relevance to the biological potential of a river, it provides an adequate index of overall reach quality, which accords well with riparian conditions derived from aerial photographs and reach-based professional judgment.

The NWHI developed in this study appears to be a valid tool for assessing habitat quality in Michigan rivers. It likely would be applicable to adjacent states and provinces, especially within the Upper Midwest where rivers are of similar size and gradient. However, its applicability to rivers of other regions, and/or larger size, is unknown. There are approximately 5000 rivers of fifth through seventh order in North America, and only 50 of eighth through tenth order (Leopold and others 1964). Thus, the vast majority of non-wadeable rivers are similar in size to those included in this study, and the largest rivers are a class to themselves. Future efforts to improve habitat assessment of non-wadeable rivers should address several issues: the extent of regional modification that is needed for the index to be effective, how metric inclusion and weighting may require modification for much larger rivers, and the ability of the NWHI to predict biological condition. Regardless, we believe that the transparent and rigorous process of metric selection and index development described here can be applied widely. 


\section{Acknowledgments}

We thank Michael Alexander for assistance with project logistics, and the Michigan Department of Environmental Quality for funding. Faith Fitzpatrick, David Galat, Phil Kaufman, Lizhu Wang, and Troy Zorn provided constructive comments on the manuscript. Field and computer assistance was provided by James Roberts, Ron Dolen, Sarah McRae, Dana Infante, Todd White, Janelle Francis, Mike Mueller, Ben Opdyke, and Liza Liversedge.

\section{Literature Cited}

Albert, D. A. 1995. Regional landscape ecosystems of Michigan, Minnesota, and Wisconsin: A working map and classification. U.S. Department of Agriculture, Forest Service, North Central Forest Experiment Station, General Technical Report NC-178.

Allan, J. D., and A. S. Flecker. 1993. Biodiversity conservation in running waters: Identifying the major factors that threaten destruction of riverine species and ecosystems. BioScience 43:32-43.

Allan, J. D., and L. B. Johnson. 1997. Catchment-scale analysis of aquatic ecosystems. Freshwater Biology 37:107-111.

Arthington, A. H., and R. L. Welcomme. 1995. The condition of large river systems of the world. Pages 44-75 in N. B. Armantrout and R. J. Wolotira, Jr. (eds.). Condition of the world's aquatic habitats. World Fisheries Congress, Science Publishers, Lebanon, NH.

Barbour, M. T., J. Gerritsen, B. D. Snyder, and J. B. Stribling. 1999. Rapid bioassessment protocols for use in streams and wadeable rivers: Periphyton, benthic macroinvertebrates and fish, second edition. U.S. Environmental Protection Agency Office of Water, Washington, D.C.

Bayley, P. B 1995. Understanding large river-floodplain ecosystems. BioScience 45:153-158.

Beisel, J. N., P. Usseglio-Polatera, and J. C. Moreteau. 2000. The spatial heterogeneity of a river sediment: A key factor determining macroinvertebrate communities. Hydrobiologia 422:163-171.

Benke, A. C 2001. Importance of flood regime to invertebrate habitat in an unregulated river-floodplain ecosystem. Journal of the North American Benthological Society 20:225-240.

Boulton, A. J 1999. An overview of river health assessment: philosophies, practice, problems, and prognosis. Freshwater Biology 41:469-479.

Brown, C. J. D. 1944. Michigan streams-their lengths, distribution, and drainage areas. Michigan Department of Natural Resources, Fisheries Division, Miscellaneous Publication 1, Ann Arbor, Michigan.

Edsall, T. A., T. E. Behrendt, G. Cholwek, J. W. Frey, G. W. Kennedy, and S. B. Smith. 1997. Use of remote sensing techniques to survey the physical habitat of large rivers. U.S. Geological Survey Great Lakes Science Center, Contribution 983 .
Fajen, O. F. and R. E. Wehnes. 1981. Missouri's method of evaluating stream habitat. Pages 117-123 in N. B. Armantrout (ed.), Acquisition and utilization of aquatic habitat inventory information. American Fisheries Society, Portland, Oregon.

Farrand W. R., D. L. Bell. 1982. Quaternary geology of Michigan. 1:500,000. Michigan Geological Survey Division, Lansing, Michigan.

Fitzpatrick, F. A., I. R. Waite, P. J. D’Arconte, M. R. Meador, M. A. Maupin, and M. E. Gurtz. 1998. Revised methods for characterizing stream habitat in the National Water-Quality Assessment Program. U.S. Geological Survey Water-Resources Investigations, 98-4052, Madison, Wisconsin.

Flotemersch, J. E., B. C. Autrey, and S. M. Cormier. 2000. Logistics of ecological sampling on large rivers. U.S. Environmental Protection Agency, EPA/600/R-00-109, Cincinnati, Ohio.

Folsom, M., and H. A. Winters. 1970. Drainage orders in Michigan. The Michigan Academician 2:79-91.

Gergel, S. E., M. G. Turner, J. R. Miller, J. M. Melack, and E. Stanley. 2002. Landscape indicators of human impacts to riverine systems. Aquatic Sciences 64:118-128.

Goldstein, R. M., D. L. Lorenz, and S. Niemela. 2000. Development of a stream habitat index for use with an index of biotic integrity in the St. Croix River Basin. U.S. Department of Interior and U.S. Geological Society, Water-Resources Investigations Report 99-4290, Mounds View, Minnesota.

Goldstein, R. M., L. Wang, T. P. Simon, and P. M. Stewart. 2002. Development of a stream habitat index for the Northern Lakes and Forests Ecoregion. North American Journal of Fisheries Management 22:452-464.

Gorman, O. T., and J. R. Karr. 1978. Habitat structure and stream fish communities. Ecology 59:507-515.

Gregory, S. V., F. J. Swanson, W. A. McKee, and K. W. Cummins. 1991. An ecosystem perspective of riparian zones. BioScience 41:540-551.

Harper, D., and M. Everard. 1998. Why should the habitatlevel approach underpin holistic river survey and management? Aquatic Conservation: Marine and Freshwater Ecosystems 8:395-413.

Hynes, H. B. N. 1989. Keynote address. Pages 5-10 in Proceedings of the International Large River Symposium (LARS), volume 106. Canadian Special Publications of Fisheries and Aquatic Science, Ottawa, Canada.

Jenks, G. F., and F. C. Caspall. 1971. Error on choroplethic maps-definition, measurement, reduction. Annals of the Association of American Geographers 61:217-244.

Johnson, B. L., W. B. Richardson, and T. J. Naimo. 1995. Past, present, and future concepts in large river ecology. BioScience 45:134-141.

Jowett, I. G 1997. Instream flow methods: a comparison of approaches. Regulated Rivers: Research and Management 13:115-127.

Junk, W. J., P. B. Bayley, and R. E. Sparks. 1989. The flood pulse concept in river-floodplain systems. Canadian Special Publications of Fisheries and Aquatic Science 106:110-127. 
Karr, J. R 1991. Biological integrity: a long-neglected aspect of water resource management. Ecological Applications 1:6684 .

Karr, J. R., and D. R. Dudley. 1981. Ecological perspective on water-quality goals. Environmental Management 5:55-68.

Kaufmann, P. R. 2000. Physical habitat characterization-non-wadeable rivers. Pages 6.1-6.29 in J. M. Lazorchak, B. H. Hill, D. K. Averill, D. V. Peck, and D. J. Klemm (eds.), Environmental monitoring and assessment program-surface waters: field operations and methods for measuring the ecological condition of non-wadeable rivers and streams. U.S. Environmental Protection Agency, Cincinnati, Ohio.

Kaufmann, P. R., P. Levine, E.G. Robison, and D. V. Peck 1999. Quantifying physical habitat in wadeable streams. U.S. Environmental Protection Agency, EPA/620/R-99/ 003, Washington, D.C.

Kellerhals, R., and M. Church. 1989. The morphology of large rivers: characterization and management. Pages 31-48 in D. P. Dodge (ed.), Proceedings of the International Large River Symposium (LARS), volume 106. Canadian Special Publications of Fisheries and Aquatic Science, Ottawa, Canada.

Ladson, A. R., L. White, J. A. Doolan, B. L. Finlayson, B. T. Hart, S. Lake, and J. W. Tilleard. 1999. Development and testing of an Index of Stream Condition for waterway management in Australia. Freshwater Biology 41:453-468.

Lazorchak, J. M., B. H. Hill, D. K. Averill, D. V. Peck, and D. J. Klemm. 2000. Environmental monitoring and assessment program-surface waters: Field operations and methods for measuring the ecological condition of non-wadeable rivers and streams. Environmental Protection Agency, EPA/620/R-00/007, Cincinnati, Ohio.

Lehtinen, R. M., N. D. Mundahl, and J. C. Madejczyk. 1997. Autumn use of woody snags by fishes in backwater and channel border habitats of a large river. Environmental Biology of Fishes 49:7-19.

Leopold, L. B., M. G. Wolman, and J. P. Miller. 1964. Fluvial processes in geomorphology. W. H. Freeman and Company, San Francisco, California.

Lewis, J. B., and P. N. Riebel. 1984. The effect of substrate on burrowing freshwater mussels (Unionidae). Canadian Journal of Zoology 62:2023-2025.

Lyons, J., R. Piette, and K. W. Niermeyer. 2001. Development, validation, and application of a fish-based index of biotic integrity for Wisconsin's large warmwater rivers. Transactions of the American Fisheries Society 130:10771094.

Maddock, I. 1999. The importance of physical habitat assessment for evaluating river health. Freshwater Biology 41:373391.

[MDNR] Michigan Department of Natural Resources. 1991. Qualitative biological and habitat survey protocols for wadeable streams and rivers: Great Lakes and Environmental Assessment Section (GLEAS) Procedure 51. Michigan Department of Natural Resources, Surface Water Quality Division, Great Lakes Environmental Protection Assessment Section (GLEAS), Procedure 51
Meador, M. R., C. R. Hupp, T. F. Cuffney, and M. E. Gurtz. 1993. Methods for characterizing stream habitat as part of the National Water-Quality Assessment Program. U.S. Geological Survey, Open-File Report 93-408, Raleigh, North Carolina.

Mebane, C. A 2001. Testing bioassessment metrics: macroinvertebrate, sculpin, and salmonid responses to stream habitat, sediment, and metals. Environmental Monitoring and Assessment 67:293-322.

Minshall, G. W., R. C. Peterson, K. W. Cummins, T. L. Bott, J. R. Sedell, C. E. Cushing, and R. L. Vannote. 1983. Interbiome comparison of stream ecosystem dynamics. Ecological Monographs 53:1-25.

Muhar, S., and M. Jungwirth. 1998. Habitat integrity of running waters-assessment criteria and their biological relevance. Hydrobiologia 386:195-202.

Norris, R. H., and M. C. Thoms. 1999. What is river health? Freshwater Biology 41:197-209.

[Ohio EPA] Ohio Environmental Protection Agency. 1989. Biological criteria for the protection of aquatic life. Vol. III. Standardized field sampling and laboratory methods for assessing fish sampling and macroinvertebrate communities. Ohio EPA, Division of Water Quality Monitoring and Assessment, Columbus, Ohio.

Omernik, J. M. 1976. The influence of land-use on stream nutrient levels. Eutrophication Survey Branch, Corvallis Environmental Research Laboratory, Environmental Protection Agency Office of Research and Development, Corvallis, Oregon.

Petts, G. E. 1996. Sustaining the ecological integrity of large floodplain rivers. Pages 535-551 in M. G. Anderson, D. E. Walling, P. D. Bates (eds.), Floodplain processes. John Wiley \& Sons Ltd, Chichester, UK.

Plafkin, J. L., M. T. Barbour, K. D. Porter, S. K. Gross, and R. H. Hughes. 1989. Rapid bioassessment protocols for use in streams and rivers: benthic macroinvertebrate and fish. U.S. Environmental Protection Agency, Office of Water, EPA/444/4-89-001, Washington, D.C.

Rankin, E. T. 1995. The use of habitat assessments in water resource management programs. Pages 181-208 in W. Davis and T. Simon (eds.), Biological assessment and criteria: Tools for water resource planning and decision making. Lewis Publishers, Boca Raton, Florida.

Reash, R. J. 1999. Considerations for characterizing Midwestern large river habitats. Pages 463-474 in T. P. Simon (ed.), Assessing the sustainability and biological integrity of water resources using fish communities. CRC Press, Boca Raton, Florida.

Richards, C., L. B. Johnson, and G. E. Host. 1996. Landscape-scale influences on stream habitats and biota. Canadian Journal of Fisheries and Aquatic Science 53(Suppl 1):295-311.

Richards, R. P 1990. Measures of a flow variability and a new flow-based classification of Great Lakes tributaries. Journal of Great Lakes Research 16:53-70.

Roth, N. E., J. D. Allan, and D. L. Erickson. 1996. Landscape influences on stream biotic integrity assessed at multiple spatial scales. Landscape Ecology 11:141-156. 
Schiemer, F. 2000. Fish as indicators for the assessment of the ecological integrity of large rivers. Hydrobiologia 422/ 423:271-278.

Scott, M. T., and L. A. Nielsen. 1989. Young fish distribution in backwaters and main-channel borders of the Kanawha River, West Virginia. Journal of Fish Biology 35:21-27.

Sedell, J. R., J. E. Richey, and F. J. Swanson. 1989. The river continuum concept: a basis for the expected ecosystem behavior of very large rivers? Page 49 in D. P. Dodge (ed.), Proceedings of the International Large River Symposium, volume 106. Canadian Special Publication of Fisheries and Aquatic Sciences.

Seelbach P. W., M. J. Wiley. 1997. Overview of the Michigan Rivers Inventory (MRI) Project. Michigan Department of Natural Resources, Report 97-3, Ann Arbor, Michigan.

Sheaffer, W. A., and J. G. Nickum. 1986. Backwater areas as nursery habitats for fishes in Pool-13 of the Upper Mississippi River. Hydrobiologia 136:131-139.

Sheehan, R. J., and J. L. Rasmussen. 1999. Large rivers. Pages 529-559 in C. Kohler, W. A. Hubert (eds.), Inland fisheries management in North America. 2nd edition American Fisheries Society, Bethesda, Maryland.

Simon, T. P. 1991. Development of index of biotic integrity expectations for the ecoregions of Indiana. Environmental Protection Agency, 905-9-91-025, Chicago, Illinois.

Simon, T. P., and E. R. Emery. 1995. Modification and assessment of an index of biotic integrity to quantity water resource quality in great rivers. Regulated Rivers: Research and Management 11:283-298.

Simon, T. P., and R. E. Sanders. 1999. Applying an index of biotic integrity based on great river fish communities: considerations in sampling and interpretation. Pages 475506 in T. P. Simon (ed.), Assessing the sustainability and biological integrity of water resources using fish communities: considerations in sampling and interpretation. CRC Press, Boca Raton, Florida.

Simonson, T. D., J. Lyons, and P. D. Kanehl. 1994. Guidelines for evaluation of fish habitat in Wisconsin streams. USDA Forest Service, General Technical Report NC-164, St. Paul, Minnesota.

Stalnaker, C. B., R. T. Milhous, and K. D. Bovee. 1989. Hydrology and hydraulics applied to fisheries management in large rivers. Page 13 in D. P. Dodge (ed.), Proceedings of the International Large River Symposium, volume 106. Canadian Special Publication of Fisheries and Aquatic Sciences, Ottawa, Canada.
Stevenson, N. J., and K. E. Mills. 1999. Streambank and shoreline condition. Pages 115-124 in M. B. Bain, N. J. Stevenson (eds.), Aquatic habitat assessment: Common methods. American Fisheries Society, Bethesda, Maryland.

Thorp, J. H 1992. Linkage between islands and benthos in the Ohio River, with implications for riverine management. Canadian Journal of Fisheries and Aquatic Science 49:1873-1882.

Thorp, J. H., and M. D. Delong. 1994. The riverine productivity model: an heuristic view of carbon sources and organic processing in large river ecosystems. Oikos 70:305308.

Vannote, R. L., G. W. Minshall, K. W. Cummins, J. R. Sedell, and C. E. Cushing. 1980. The river continuum concept. Canadian Journal of Fisheries and Aquatic Sciences 37:130137.

Wang, L., J. Lyons, and P. D. Kanehl. 1998. Development and evaluation of a habitat rating system for low-gradient Wisconsin streams. North American Journal of Fisheries Management 18:775-785.

Wang, L., J. Lyons, P. D. Kanehl, and R. Gatti. 1997. Influences of watershed land use on habitat quality and biotic integrity in Wisconsin streams. Fisheries 22:6-12.

Wehrly, K. E., M. J. Wiley, and P. W. Seelbach. 1998. A thermal habitat classification for lower Michigan rivers. Michigan Department of Natural Resources, Fisheries Division, Fisheries Research Report 2038, Lansing, Michigan.

Wessell, K. J. 2004. Biological evaluation of non-wadeable rivers in Michigan. Ph.D. thesis. Michigan State University, East Lansing, Michigan.

Wiley, M. J., and P. W. Seelbach. 1997. An introduction to rivers-The conceptual basis for the Michigan Rivers Inventory (MRI) Project. Michigan Department of Natural Resources, Fisheries Division, Fisheries Special Report 20, Ann Arbor, Michigan.

Wilhelm, J. G. O. 2002. A habitat rating system for nonwadeable rivers of Michigan. M.S. thesis. University of Michigan, Ann Arbor, Michigan.

Wright, J. F. 1995. Development and use of a system for predicting the macroinvertebrate fauna in flowing waters. Australian Journal of Ecology 20:181-197.

Zorn, T. G., P. W. Seelbach, and M. J. Wiley. 2002. Distributions of stream fishes and their relationship to stream size and hydrology in Michigan's lower peninsula. Transactions of the American Fisheries Society 131:70-85. 